\title{
Evidence Summary: the relationship between oral health and pulmonary disease
}

Deborah Manger ${ }^{1}$, Martin Walshaw ${ }^{2}$, Richard Fitzgerald ${ }^{3}$, Janine Doughty ${ }^{4}$, Kristina L Wanyonyi ${ }^{3}$, Sandra White ${ }^{4}$, Jennifer E Gallagher ${ }^{3,4}$

\author{
Deborah Manger \\ Deputy Medical Director \\ Specialist in Special Care Dentistry \\ Northamptonshire Healthcare NHS Foundation Trust \\ Salaried Primary Care Dental Service \\ Willowbrook Health Centre, Cottingham Road, Corby, NN17 2UR \\ Telephone: 01536748044 (admin) \\ deborah.manger@nhft.nhs.uk
}

Dr Martin Walshaw MD FRCP

Honorary Professor of Medicine, Department of Infection Microbiology and Immunology, Liverpool University and Consultant Chest Physician

Liverpool Heart and Chest Hospital

Thomas Drive,

Liverpool L14 3PE

Mwalshaw@doctors.org.uk

Richard Fitzgerald

Formerly Dental Core Trainee in Community Special Care Dentistry/Dental Public Health/Honorary Research Assistant

King's College London Dental Institute

Denmark Hill Campus

Bessemer Road, London SE5 9RS

Telephone: 07831359857

richard.fitzgerald@kcl.ac.uk

Dr Janine Doughty

Formerly Clinical Fellow in Special Care Dentistry, Northampton Healthcare NHS Foundation Trust Academic Clinical Fellow in Special Care Dentistry

Eastman Dental Hospital

University College London

256 Gray's Inn Road, London WC1X 8LD

janine.doughty4@nhs.net

Dr Kristina L Wanyonyi

(Formerly Research Associate, King's College London Dental Institute, Population and Patient Health)

Senior Lecturer in Dental Public Health

University of Portsmouth Dental Academy

William Beatty Building, Hampshire Terrace,

Portsmouth PO1 2QG

kristina.wanyonyi@port.ac.uk

Dr Sandra White

Director of Dental Public Health

Population Health \& Care Division

Health and Wellbeing Directorate

Public Health England 
Skipton House

80 London Road

London SE1 6LH

Tel: $\quad+44(0) 2036820911$

Mobile: 07917184998

sandra.white@phe.gov.uk

Professor Jennifer E Gallagher MBE

Head of Population and Patient Health

Newland Pedley Professor of Oral Health Strategy

Honorary Consultant in Dental Public Health

King's College London Dental Institute

Denmark Hill Campus. Bessemer Road, London SE5 9RS

jenny.gallagher@kcl.ac.uk

\section{Corresponding author}

Professor Jennifer E Gallagher MBE

Head of Population and Patient Health

Newland Pedley Professor of Oral Health Strategy

Honorary Consultant in Dental Public Health

King's College London Dental Institute

Denmark Hill Campus. Bessemer Road, London SE5 9RS

Telephone 02032995171/3481 Admin (research)

jenny.gallagher@kcl.ac.uk

\section{Words}

Oral health, general health. Pulmonary disease, pneumonia, COPD, ventilated, community living, oral health, oral hygiene, chlorhexidine. Tooth brushing 


\title{
In brief
}

- There is moderate evidence of an association between oral health and two pulmonary conditions: chronic obstructive pulmonary disease (COPD) and pneumonia. COPD is associated with periodontal disease, while pneumonia is associated with dental caries and the presence of oral plaque, with evidence stronger for the latter condition.

- Moderate evidence suggests that toothbrushing reduces the incidence, duration, and mortality associated with pneumonia in community-living and hospital-based patients, but has no effect on pneumonia when used alone in ventilated patients. However, studies linking toothbrushing to a reduction in mortality advised caution due to possible bias.

- There is strong evidence that frail populations (such as ventilated, or community-living and hospital-based patients) would have a lower incidence of pneumonia after regular oral hygiene interventions which include use of chlorhexidine or povidone iodine, with stronger evidence supporting chlorhexidine in mouthwash, gel, or other forms.

- Although evidence suggests that chlorhexidine reduces the incidence of ventilator-associated pneumonia, other outcomes such as mortality are not affected in ventilated patients. Further research should explore this.

\begin{abstract}
This paper reports the one of four reviews exploring the relationships between oral health and general medical conditions, in order to support teams within Public Health England, health practitioners and policymakers. This review aimed to explore the most contemporary evidence on whether poor oral health and pulmonary disease occurs in the same individuals or populations, to outline the nature of the relationship between these two health outcomes, and to discuss the implication of any findings to health services and future research. The work was undertaken by a group comprising consultant clinicians from medicine and dentistry, trainees, public health, and academics. The methodology involved a streamlined rapid review process and synthesis of the data. The results identified a number of systematic reviews of medium to high quality which indicate that there is evidence that oral health and oral hygiene habits have an impact on incidence and outcomes of lung diseases, such as pneumonia and COPD in people living in the community and in long term care facilities. The findings are discussed in relation to the implications for service and future research.
\end{abstract}




\section{Background}

Pulmonary diseases can be broadly divided into lung infections, lung cancer, and those which obstruct airflow (chronic obstructive pulmonary disease and asthma). Lung cancer, chronic obstructive pulmonary disease (COPD), and lower respiratory tract infections were three of the top six causes of years of life lost in England in 2013 (1). COPD and lung cancer are major causes of morbidity and mortality throughout the world. Pneumonia occurs in 1-2 individuals per 1000 (2), caused over 5\% of all deaths for all ages in 2014 (3), and, together with influenza, accounted for the second-most hospital bed days in the UK in 2014-2015 (4).

Pneumonia is an inflammation of the lung, usually caused by infection (5). Three common causes are bacteria, viruses, and fungi some of which can colonise the oral cavity and upper airway (6). It is also possible to contract pneumonia by accidentally inhaling a liquid or chemical. People most at risk are over 65 or below two years of age, or already have health problems, e.g. mechanically ventilated patients with respiratory problems who have an endotracheal tube placed from the oral cavity to the trachea to ensure a patent airway.

Ventilator-associated pneumonia (VAP) is a known complication of mechanical ventilation and defined as "serious inflammation of the lung in patients who required the use of pulmonary ventilator"(5). A patient may be ventilated for several reasons, primarily when they require critical care in intensive care units (ICUs) such as post-cardiac surgery, trauma, neurological or respiratory conditions, and for varying time periods.

Chronic obstructive pulmonary disease is a type of obstructive lung disease characterized by chronically poor airflow. The main symptoms include shortness of breath, cough, and sputum. Tobacco smoking is the most common cause of COPD, with a number of other factors such as air pollution and genetics playing a smaller role (5). It is diagnosed by a combination of clinical judgement, patient factors, and spirometry.

The two most common diseases affecting oral health are dental caries and periodontitis. Dental caries (caries) is the localised destruction of susceptible dental hard tissues by acidic by-products from bacterial fermentation of dietary carbohydrates (7). Periodontitis is a chronic inflammatory disease caused by bacterial infection of the supporting tissues around the teeth (8). Approximately half of all adults in the UK are affected by some level of irreversible periodontitis, which increases with age, and almost a third have obvious dental decay (9).

It is suggested that there is biological plausibility for a causal link between pulmonary disease and oral health-related to oral disease pathogens aspirated into the pulmonary tissues. In the absence of effective oral care, initial plaque formation will occur within forty-eight hours; the composition of the oropharyngeal flora becomes more heavily colonised by virulent gram-negative pathogens that, as well as leading to oral disease, may be transported to the lungs where they have the potential to cause respiratory infections (10). The aim of good mouth care is to maintain oral cleanliness, remove plaque and thereby prevent infection (11). Twice daily brushing is recommended to control both periodontal 
diseases and caries (12); however, the extent to which this may impact on pulmonary disease is unclear. In view of the serious outcomes and high prevalence related to both pulmonary and oral diseases, the aim of this review is to collate the most contemporary evidence on any links between the two.

\section{Methods}

A rapid review methodology was employed to synthesise the evidence from articles published between 2005 and 2015 that explored the relationship between pulmonary and oral health. A rapid review is a synthesis of the most current and best evidence to inform decision-makers (13). It combines elements of systematic reviews with a streamlined approach to summarise available evidence in a timely manner.

Search syntax was developed based on subject knowledge, MeSH terms, and task group agreements (Figure 1); followed by duplicate systematic title and abstract searches of three electronic databases: Cochrane, PubMed, OVID (Embase, MEDLINE (R), and PsycINFO). Two independent searches were carried out: screening papers by abstract, and title, for relevance and duplication.

Figure 1

Studies were included if they were either a systematic review and/or meta-analysis, and explored a link between pulmonary and oral health. Disagreements between the reviewers and the wider research group were resolved by discussion. Papers were excluded for the following reasons: did not mention any term related to oral health or pulmonary health; were not available in English or in full text after contacting primary authors; or if a more up-to-date review covering the same topics by the same authors was found.

The following information were extracted from each paper: author, year, population studied, oral disease/intervention, definitions used, methods, comparison/intervention and controls, outcomes, results, authors' conclusions, quality and quality justification, as shown in data extraction Table 1 (full table available on request).

\section{Table 1}

From a total of 272 papers initially identified based on title and abstract, 35 remained after removal of duplicates, title screening and reviewing abstracts for relevance. These papers were examined in full and 23 papers were identified as relevant for the rapid review and synthesis of findings. A flow diagram of the process is provided in Figure 2.

\section{Figure 2}


Papers were reviewed and the following themes identified: association between oral health and pulmonary diseases; association of oral health interventions with the onset and outcomes of pneumonia in both (i) community-living and non-ventilated hospital-based patients (henceforth referred to simply as "community" and "hospital" patients respectively); and (ii) ventilated patients. The majority of evidence relates to patients who had difficulty in managing, or were unable to manage, their own oral hygiene measures; this included children, older people, patients with dementia, mechanically ventilated patients, and patients with functional disabilities and/or critical illness.

Quality assessment was undertaken for each systematic review. An AMSTAR assessment was carried out on all papers with the methodological quality of the review being rated as "High" with a score between eleven and eight, "Moderate" between seven and four, and "Low" between four and zero. The quality of all papers was also assessed by group discussion to reinforce the conclusion reached by the quality score.

The quality of the selected studies varied. Of the 23 systematic reviews, 13 were deemed to be high quality in line with the AMSTAR scoring system, following group discussion. Nine papers were found to be of moderate and one of low quality. Common AMSTAR missing points were the inclusion of grey literature, the listing of excluded papers with reasons for their exclusion, and the quality assessment of the included studies. Quality scores, as well as rationale for these scores, are presented for each paper included in this review in the data extraction table (Table 1).

Within the themes identified by this review, the papers examining oral hygiene interventions in ventilated patients were particularly of strong quality (14-25), with all but five systematic reviews (21, $23,24,26,27$ ) of high quality, while the systematic reviews examining community and hospital patients were more mixed with three of high (28-30), and three of moderate quality (31-33). Finally, the papers examining a direct association between oral health and pulmonary diseases were all of moderate quality (33-35).

\section{Results: evidence synthesis}

This section is reported in two main sections. First, the nature of association between oral and pulmonary disease, including whether or not pulmonary disease is more likely in patients with oral disease. Second, the evidence that describes studies that have tested the impact of oral hygiene measures on pulmonary disease incidence and outcomes.

\section{A] Association between oral and pulmonary disease}

Overall the literature suggests associations of varying strength between oral health (periodontitis, caries, and plaque) and pulmonary disease (COPD and pneumonia). This was demonstrated by the increased presence of oral disease, or oral pathogens, in those participants who developed pulmonary disease when compared with those who did not. No evidence was discovered regarding any association between oral health and the presence of other conditions, notably lung cancer or tuberculosis. In the 
next sections, evidence of the associations between individual oral diseases and COPD and pneumonia are presented.

\section{1] Periodontitis and COPD}

In the case of periodontitis and COPD, three reviews of moderate methodological quality highlight an association between COPD and periodontal disease. The first, by Azarpazhooh and Leake (35), provided weak evidence of an association between COPD and periodontal disease, suggesting study participants with significantly higher alveolar bone loss (ABL) and loss of clinical attachment had a higher risk of COPD than their counterparts. The second review by Sjogren et al. (33), also highlighted a weak association between $A B L$ and dental plaque with COPD. And a third by Zeng et al. (34), reviewed fourteen observational studies assessing the relationship between COPD and periodontal disease and included pooled data stratified to control for smoking and other risk factors associated with the two diseases; the stratified results showed an attenuated, but significant, association between COPD and periodontal disease $(p<0.001)$.

\section{II] Periodontitis and Pneumonia}

Azarpazhooh and Leake (2006) (35) reviewed five studies that explored the relationship between pneumonia and oral health, suggesting that periodontal pathogens in saliva are a potentially important risk factor for pneumonia. No evidence was found linking periodontal disease itself with pneumonia.

\section{III] Caries and pneumonia}

The presence of caries was linked to the development of pneumonia in one moderate quality review (35), which reported evidence from a nine-year cohort study that decayed teeth (i.e. dental caries) ([OR] $\sim 1.2$ per decayed tooth) and cariogenic bacteria in saliva and plaque ([OR] 4 to 9.6) were associated with a higher risk of pneumonia (35).

\section{IV] Plaque and pneumonia}

Plaque, and its association with pulmonary disease, was examined by one moderate quality review. The evidence to support this was mixed with two prospective cohort studies suggesting that higher plaque scores were associated with a previous history of respiratory tract infection, whilst a third found no such significant association between pneumonia and plaque scores (35).

In summary, there is moderate evidence to suggest that patients with caries and plaque have a higher likelihood of developing pneumonia, and weak evidence suggesting an increased likelihood of people with more alveolar bone loss developing COPD than comparable counterparts. 


\section{B] Effect of oral hygiene interventions on incidence and outcomes of pulmonary disease}

In this section the impact of oral hygiene interventions is reported in two sub-sections: first in relation to community or hospital patients; and, second, in relation to ventilated patients.

1] Effect of oral hygiene interventions on incidence and outcomes of pulmonary disease in community or hospital patients

Several reviews described oral hygiene interventions and their impact on incidence, or outcomes, of pneumonia in non-ventilated patients in community or hospital environments, while no evidence was found regarding any other pulmonary disease (including COPD). Therefore, this section will solely deal with oral hygiene inventions and their effects on pneumonia. These interventions include the use of chlorhexidine with concentrations between 0.12 to $2.0 \%$, povidone iodine, the cleaning of prostheses, and mechanical interventions such as toothbrushing or professional care involving scaling and polishing.

a) Incidence of pneumonia in community and hospital patients

Seven systematic reviews investigated the relationship between oral hygiene interventions and incidence of pneumonia in these patients, and all suggest there is good evidence that oral hygiene interventions (chlorhexidine, toothbrushing, professional oral care, povidone iodine) reduce the risk of pneumonia $(28-33,35)$. The review quality ranged from high $(16,26,28)$, which included a metaanalysis, to moderate $(31-33,35)$. Two reviews suggest that there is a reduced risk of pneumonia with combined effect of mechanical and professional care $(28,33)$, and a third by Van der Maarel-Wierink et al. (32) suggests that manual toothbrushing, with or without povidone iodine, reduced the risk of pneumonia in frail older people by $67 \%$. Of note, while mechanical plaque removal was shown to reduce pneumonia incidence in non-ventilated patients, this result was not repeated for ventilated patients.

In summary, there is good evidence that oral hygiene interventions reduce the risk of pneumonia in community and hospital patients.

\section{b) Outcomes of pneumonia}

Three high to moderate quality reviews found that mortality was reduced by mechanical plaque removal in community and hospital patients. $(19,28,32)$. One high quality review by Silvestri et al. suggested no significant impact of chlorhexidine on pneumonia-associated mortality, although this paper included both ventilated and non-ventilated hospital patients (29). Kaneoka et al. (28), in a high quality review, suggest that there is moderate evidence from two randomised, controlled trials, that mechanical oral care can lead to a risk reduction in fatal pneumonia but highlight a need for caution due to a risk of possible bias in the included studies (19). Similarly, two studies included in the systematic review by Van der Maarel-Wierink et al. (32), found that toothbrushing without povidone iodine reduced pneumonia mortality $(\mathrm{RR}=2.40$ and $95 \% \mathrm{Cl}=1.54-3.74$ and $\mathrm{OR}=3.57 ; 95 \% \mathrm{Cl}=$ 1.13-13.70). 
Two high quality reviews suggest that the number of febrile days may be reduced by implementing oral health interventions $(17,29)$. One review found that toothbrushing with $1 \%$ iodine, or scaling combined with electric toothbrushing led to a reduction in febrile days (30). These reviews do not include meta-analysis and should therefore be considered with caution.

Use of topical antiseptics and professional oral health care both appear to reduce microbial colonisation of the oral cavity. In a high quality review, Silvestri et al. (29), report that chlorhexidine controls both gram-positive and gram-negative bacteria-related pneumonia as well as most (but not all) specific pneumonia-causing bacteria such as Streptococcus pneumoniae or Haemophilus influenza. However, when micro-organisms are classified into "normal" and "abnormal", chlorhexidine significantly reduces pneumonia due to "normal" flora only (29). One study in the review by Van der Maarel-Wierink et al. (32), suggests a reduction in levels of potential respiratory pathogens (Streptococci, Staphylococci, Candida, Pseudomonas, and Black-pigmented Bacteroides species) after weekly professional oral health care. Professional oral care being defined as mechanical cleaning by a dentist/hygienist which varied in frequency from one- to three-times weekly.

A moderate quality review by Van der Maarel-Wierink et al., which examined known risk factors for aspiration pneumonia reported an improvement in four out of five risk factors (swallowing latency time, activities of daily living scale, swallowing reflex, cough reflex sensitivity; but not salivary substance $\mathrm{P}$ ) associated with regular oral hygiene (32).

In summary, good to moderate evidence suggests that oral hygiene interventions reduce many of the outcomes of pneumonia including febrile days, microbial colonisation, and mortality with the latter primarily being reduced by mechanical plaque removal.

II] The effect of oral hygiene interventions on incidence and outcomes of pulmonary disease in ventilated patients

There is a significant body of evidence relating to the effect of oral hygiene interventions on VAP, although no evidence regarding any other pulmonary disease. Again, this section focused on pneumonia as the pulmonary disease outcome.

\section{a) Incidence of VAP}

In mechanically ventilated patients there is strong evidence from 13 systematic reviews that use of chlorhexidine (gel or mouthwash), when used in concentrations varying from $0.12-2.0 \%$, reduces the risk of incidence of $\operatorname{VAP}(14,16-21,24,26,27,29-31)$. Only one moderate-quality study (25), the oldest included, did not find a significant reduction. The pooled relative risk of acquiring VAP reduced by approximately $40 \%$ when chlorhexidine-based oral decontamination was provided to ventilated patients in comparison to control groups (specifics of control groups varied among studies and included toothbrushing, "standard oral care", placebo, other oral decontaminants, sterile water. Five reviews (two high, two moderate and one low quality) suggest the number needed to treat (NNT) as 
between 8 and 21 (with the high quality reviews finding a NNT of 14 and 15); meaning that between 8 and 21 ventilated patients in intensive care need to receive chlorhexidine oral decontamination for one case of VAP to be prevented $(20,22,26,27,33)$. Mechanical toothbrushing in addition to the use of chlorhexidine was not found to reduce the incidence of VAP by three high quality, and one moderate quality reviews $(14,15,20,23)$.

In summary, there is strong evidence that regular chlorhexidine use in ventilated patients reduces the risk of VAP; with no evidence to show that mechanical plaque removal in addition to chlorhexidine provides further benefit.

\section{b) Outcomes of VAP}

No significant effect on mortality, duration of mechanical ventilation or duration of hospital stay was demonstrated (14, 17-20, 22, 24-26), and no evidence was found of a difference between chlorhexidine and placebo for the outcomes of VAP and mortality in children (20). Other notable outcomes were that the use of chlorhexidine had a greater treatment effect in cardio-surgical patients $(24,29,36)$, and authors postulated that this was related to the planned nature of the intubation and the physical status of the patient at the time.

In relation to the impact of oral interventions on the use of systemic antibiotic therapy, Shi et al (20), a high quality review based on two randomised clinical trials, reported no significant difference in duration of antibiotic therapy, for the management of VAP, between intervention and control groups. One high quality systematic review, including four randomised-controlled trials, found no significant difference in antibiotic-free days between patients who received oral care and the control group (15).

Four reviews $(20,23,24,30)$ high to medium quality include evidence regarding oral health indices, in particular plaque scores. El-Rabbany et al (30), in a high quality review suggest that toothbushing does improve oral health and has a positive effect on plaque scores when used on ventilated patients. It is suggested that this will reduce VAP, although as mentioned above, four reviews found toothbrushing had no effect. They do clarify that the studies reviewed were of moderate to high risk of bias. Two reviews $(23,24)$, report lower plaque levels in chlorhexidine groups versus controls in five trials, while one trial showed no such difference.

Shi et al (20), reported the effect on plaque scores for toothbrushing versus no brushing and the use of chlorhexidine plus brushing versus a control group with chlorhexidine alone. The studies were of moderate to high risk of bias and presented ambivalent conclusions, when compared. One study indicated that plaque scores were improved, whereas the other three showed no difference.

In relation to microbial colonisation, Shi et al., found insufficient reliable and consistent evidence to confirm whether microbial colonisation of dental plaque varied between intervention and control groups for VAP (20). On adverse effects of the interventions, two high and one moderate quality reviews $(18,20,24)$, considered adverse effects in the evidence from the studies they included. One 
study reported that three patients receiving chlorhexidine complained of a transient, unpleasant taste and this compared to five patients in the control arm of the study (20). In a further study, $9.8 \%$ of patients receiving chlorhexidine complained of mucosal irritation compared with $1 \%$ of the control group (20). Snyder et al (18), concurred with the comments from this study but added that further instruction to staff to be more gentle, reduced the reports of irritation. Chlebicki et al. (24), reported no adverse effects.

Adverse effects/side effects reported were transient in nature and were reported in relation to chlorhexidine intervention and the control groups. The adverse effects of chlorhexidine were not unexpected and are those described within the drug proprietary literature. There was no reported evidence on the effect of oral hygiene interventions on the number of febrile days for ventilated patients.

In summary, there is moderate to low quality evidence that chlorhexidine does not have an effect on the following outcomes of VAP: mortality, duration of hospital stay, duration of ventilation, antibiotic use, plaque scores, microbial colonisation; or VAP in children. No unexpected side-effects of chlorhexidine were found.

\section{c) Cost-effectiveness}

Three systematic reviews reported on the cost-effectiveness of chlorhexidine as an oral care intervention $(16,18,24)$. Where chlorhexidine reduced the incidence of VAP by $43 \%$, the comparative cost of a year's supply of chlorhexidine (Peridex) was less than $10 \%$ of the cost associated with a single case of VAP (16). The cost of chlorhexidine therapy for fourteen patients was suggested to be less than $10 \%$ of the cost of antibiotic therapy alone for one case of VAP (16).

Snyders et al (18), also included two trials that considered the cost-effectiveness of chlorhexidine. Both suggested that chlorhexidine was cost-effective, and one suggested that the cost-effectiveness may be as much as ten times less per patient than the cost of antibiotics to treat VAP (18). Chlebicki et al. (24) quotes studies examining costs of chlorhexidine, but notes no formal cost-effective analysis was found.

In summary, good evidence suggests that chlorhexidine is cost-effective when used to reduce pneumonia incidence.

\section{d) Other antimicrobial agents}

The effectiveness of topical application of povidone iodine for oral disinfection was considered in five systematic reviews of which four were high quality $(16,19,27,29)$. There is weak evidence that povidone iodine reduces the incidence of pneumonia, but this mode of oral disinfection was less effective than the use of chlorhexidine $(17,20,28,30,32)$. 
In summary, moderate evidence suggests both mechanical and chemical interventions have an impact on the incidence and outcomes of pneumonia in community and hospital patients. In regards to VAP, there is strong evidence that chemical interventions in general reduce incidence but do not affect other patient outcomes.

\section{Summary}

The cumulative evidence of this review suggests an association between oral and pulmonary disease, specifically COPD and pneumonia, and incidence of the latter can be reduced by oral hygiene measures such as chlorhexidine and povidone iodine in all patients, while toothbrushing reduces the incidence, duration, and mortality in community and hospital patients.

This review has a number of strengths and limitations which should be recognised. First, the review process conducted by a multidisciplinary team containing medical, dental, and public health professionals allowed for broad input and feedback and was thus considered a strength. Second, this is a "rapid review", and so was intended to summarise existing evidence, rather than undertake quantitative synthesis of evidence. Third, there was large heterogeneity in the methodology of the studies in the literature reviewed including: variations in oral care interventions, varying measures of the chemical interventions such as chlorhexidine, and varying definitions/diagnoses of oral and pulmonary diseases; none-the-less there is important learning to inform future research.

The evidence has significant implications for research and services. First, the findings that highlight a reduction in the incidence of pneumonia in community and hospital patients after the implementation of oral hygiene measures (namely: toothbrushing, chlorhexidine, professional oral cleaning, and povidone iodine), provide useful data in planning for the oral health components of care pathways for patients with pneumonia. Second, a number of reviews demonstrated a reduction in the incidence of pneumonia after both chlorhexidine use and toothbrushing in community and hospital patients; and some studies, with a high risk of bias, additionally suggested that toothbrushing reduced the duration (days of fever) and mortality of pneumonia. Overall this evidence supports the implementation of oral health protocols for pneumonia patients.

There was a greater volume of evidence on the role of oral hygiene interventions in reducing the incidence of VAP. Chlorhexidine was shown to be effective in reducing the incidence of VAP which has implications for patient well-being, and cost-effective, without unexpected or severe adverse effects. In contrast to non-ventilated patients, toothbrushing alone had no effect on VAP incidence.

There is a clear need for further research, particularly around the cost-effectiveness and feasibility of implementation of oral hygiene interventions and their outcomes, as part of the care pathway for community-living and hospitalised frail patients in particular (Table 2).

\section{Table 2}

Although chlorhexidine was found to reduce the incidence of pneumonia as outlined in the paragraph above; other outcomes related to VAP, such as mortality or duration of ventilation/hospital-stay, were 
not affected by either chlorhexidine or toothbrushing. This seems contradictory and certainly warrants further investigation, especially as a low sample size and low attributable mortality of VAP may be the explanation (37).

So what can and should clinicians caring for community, hospital and ventilated patients do while waiting for this research? Daily oral care is central to oral health for everyone. Numerous guidelines (38-40) recommend regular oral care in older people to prevent oral disease and maintain oral health. Alongside these benefits, patients, carers, and relatives should be informed that improved oral hygiene may prevent episodes of pneumonia, and has been shown in some studies to reduce the incidence of mortality. In order to maintain optimal oral health, mechanical plaque removal by twicedaily toothbrushing is recommended (12), the preventative effects of oral hygiene for the reduction of pneumonia can be further augmented by the oral application of chlorhexidine mouthwash, gels or other forms of delivery.

Where possible, this regimen can be carried out by the patient, and where not, a regular oral care plan should be created, implemented, and reviewed at regular intervals, either by or in consultation with a dental professional. To prevent and improve the outcomes of pneumonia, commissioners and managers of services are advised to provide oral hygiene training for carers. Improving patients', relatives' and carers' knowledge of the effects of poor oral health has the potential to support health maintenance in vulnerable patients, deliver cost-effective care, and improve patient quality of life.

\section{Acknowledgements}

We would like to acknowledge the support of Public Health England, the Royal College of Surgeons, and the British Dental Association. 


\section{References}

Bibliography

1. Newton JN, Briggs AD, Murray CJ, Dicker D, Foreman KJ, Wang $\mathrm{H}$, et al. Changes in health in England, with analysis by English regions and areas of deprivation, 1990-2013: a systematic analysis for the Global Burden of Disease Study 2013. Lancet. 2015;386(10010):2257-74.

2. Torres A, Peetermans WE, Viegi G, Blasi F. Risk factors for community-acquired pneumonia in adults in Europe: a literature review. Thorax. 2013;68(11):1057-65.

3. Office for National Statistics. Mortality Statistics: Deaths Registered in England and Wales (Series DR).2014 24/01/2016. Available from:

http://www.ons.gov.uk/peoplepopulationandcommunity/birthsdeathsandmarriages/deaths/bulletin s/deathsregistrationsummarytables/2015-07-15.

4. Health and Social Care Information Centre. Hospital Episode Statistics, Admitted Patient Care - England, 2014-15 [NS]. 2015.

5. World Health Organisation. International Statistical Classification of Diseases and Related Health Problems 10th Revision. 2016.

6. Scannapieco FA, Shay K. Oral health disparities in older adults: oral bacteria, inflammation, and aspiration pneumonia. Dent Clin North Am. 2014;58(4):771-82.

7. Fejerskov O, Nyvad B, Kidd E. Dental caries: the disease and its clinical management2015.

8. Eke PI, Page RC, Wei L, Thornton-Evans G, Genco RJ. Update of the case definitions for population-based surveillance of periodontitis. J Periodontol. 2012;83(12):1449-54.

9. Steele J, O'Sullivan I. Adult Dental Health Survey2011 21/05/2011. Available from: http://www.hscic.gov.uk/catalogue/PUB01061/adul-dent-heal-surv-firs-rele-2009-rep.pdf. 10. Eley B, Manson J. Periodontics. 2004.

11. Mallett JD, Lisa. The Royal Marsden Hospital Manual of Clinical Nursing Procedures. 2000. 12. NHS Public Health England. Delivering better oral health: an evidence-based toolkit for prevention. 2014.

13. Khangura S, Konnyu K, Cushman R, Grimshaw J, Moher D. Evidence summaries: the evolution of a rapid review approach. Syst Rev. 2012;1:10.

14. Alhazzani W, Smith O, Muscedere J, Medd J, Cook D. Toothbrushing for critically ill mechanically ventilated patients: a systematic review and meta-analysis of randomized trials evaluating ventilator-associated pneumonia. Crit Care Med. 2013;41(2):646-55.

15. Gu WJ, Gong YZ, Pan L, Ni YX, Liu JC. Impact of oral care with versus without toothbrushing on the prevention of ventilator-associated pneumonia: a systematic review and meta-analysis of randomized controlled trials. Crit Care. 2012;16(5):R190.

16. Zhang TT, Tang SS, Fu LJ. The effectiveness of different concentrations of chlorhexidine for prevention of ventilator-associated pneumonia: a meta-analysis. J Clin Nurs. 2014;23(11-12):146175.

17. Li L, Ai Z, Li L, Zheng $X$, Jie L. Can routine oral care with antiseptics prevent ventilatorassociated pneumonia in patients receiving mechanical ventilation? An update meta-analysis from 17 randomized controlled trials. Int J Clin Exp Med. 2015;8(2):1645-57.

18. Snyders $\mathrm{O}$, Khondowe $\mathrm{O}$, Bell J. Oral chlorhexidine in the prevention of ventilator-associated pneumonia in critically ill adults in the ICU: A systematic review. Southern African Journal of Critical Care. 2011;27(2).

19. Klompas M, Speck K, Howell MD, Greene LR, Berenholtz SM. Reappraisal of routine oral care with chlorhexidine gluconate for patients receiving mechanical ventilation: systematic review and meta-analysis. JAMA Intern Med. 2014;174(5):751-61.

20. Shi Z, Xie H, Wang P, Zhang $Q$, Wu Y, Chen E, et al. Oral hygiene care for critically ill patients to prevent ventilator-associated pneumonia. Cochrane Database Syst Rev. 2013;8:CD008367. 
21. Kola A, Gastmeier P. Efficacy of oral chlorhexidine in preventing lower respiratory tract infections. Meta-analysis of randomized controlled trials. The Journal of hospital infection. 2007;66(3):207-16.

22. Chan EY, Ruest A, Meade MO, Cook DJ. Oral decontamination for prevention of pneumonia in mechanically ventilated adults: systematic review and meta-analysis. Bmj. 2007;334(7599):889. 23. Berry AM, Davidson PM, Masters J, Rolls K. Systematic literature review of oral hygiene practices for intensive care patients receiving mechanical ventilation. American journal of critical care : an official publication, American Association of Critical-Care Nurses. 2007;16(6):552-62; quiz 63.

24. Chlebicki MP, Safdar N. Topical chlorhexidine for prevention of ventilator-associated pneumonia: a meta-analysis. Critical care medicine. 2007;35(2):595-602.

25. Pineda LA, Saliba RG, El Solh AA. Effect of oral decontamination with chlorhexidine on the incidence of nosocomial pneumonia: a meta-analysis. Critical care. 2006;10(1):R35.

26. Balamurugan E, Kanimoxhi A, Kumari G. Effectiveness of chlorhexidine oral decontamination in reducing the incidence of ventilator associated pneumonia: a meta-analysis. British Journal of Medical Practitioners. 2012;5(1).

27. Tantipong H, Morkchareonpong C, Jaiyindee S, Thamlikitkul V. Randomized controlled trial and meta-analysis of oral decontamination with $2 \%$ chlorhexidine solution for the prevention of ventilator-associated pneumonia. Infection control and hospital epidemiology. 2008;29(2):131-6.

28. Kaneoka A, Pisegna JM, Miloro KV, Lo M, Saito H, Riquelme LF, et al. Prevention of Healthcare-Associated Pneumonia with Oral Care in Individuals Without Mechanical Ventilation: A Systematic Review and Meta-Analysis of Randomized Controlled Trials. Infect Control Hosp Epidemiol. 2015;36(8):899-906.

29. Silvestri L, Weir I, Gregori D, Taylor N, Zandstra D, Van Saene JJ, et al. Effectiveness of oral chlorhexidine on nosocomial pneumonia, causative micro-organisms and mortality in critically ill patients: a systematic review and meta-analysis. Minerva Anestesiol. 2014;80(7):805-20.

30. El-Rabbany M, Zaghlol N, Bhandari M, Azarpazhooh A. Prophylactic oral health procedures to prevent hospital-acquired and ventilator-associated pneumonia: a systematic review. Int J Nurs Stud. 2015;52(1):452-64.

31. Vilela MC, Ferreira GZ, Santos PS, Rezende NP. Oral care and nosocomial pneumonia: a systematic review. Einstein (Sao Paulo). 2015;13(2):290-6.

32. van der Maarel-Wierink CD, Vanobbergen JN, Bronkhorst EM, Schols JM, de Baat C. Oral health care and aspiration pneumonia in frail older people: a systematic literature review.

Gerodontology. 2013;30(1):3-9.

33. Sjogren $\mathrm{P}$, Nilsson $\mathrm{E}$, Forsell $\mathrm{M}$, Johansson $\mathrm{O}$, Hoogstraate J. A systematic review of the preventive effect of oral hygiene on pneumonia and respiratory tract infection in elderly people in hospitals and nursing homes: effect estimates and methodological quality of randomized controlled trials. Journal of the American Geriatrics Society. 2008;56(11):2124-30.

34. Zeng XT, Tu ML, Liu DY, Zheng D, Zhang J, Leng W. Periodontal disease and risk of chronic obstructive pulmonary disease: a meta-analysis of observational studies. PloS one. 2012;7(10):e46508.

35. Azarpazhooh A, Leake JL. Systematic review of the association between respiratory diseases and oral health. J Periodontol. 2006;77(9):1465-82.

36. Labeau SO, Van de Vyver K, Brusselaers N, Vogelaers D, Blot SI. Prevention of ventilatorassociated pneumonia with oral antiseptics: a systematic review and meta-analysis. The Lancet Infectious diseases. 2011;11(11):845-54.

37. Damjanovic V, Silvestri L, Taylor N, van Saene HK, Piacente N. Oropharyngeal without intestinal decontamination does not make sense. The Journal of hospital infection. 2014;86(4):277-8. 38. Guidelines and Audit Implementation Network. Guidelines for the Oral Healthcare of Older People Living in Nursing and Residential Homes in Northern Ireland2012 25/01/2016. Available from: 
http://www.hscic.gov.uk/searchcatalogue?productid $=19420 \& q=$ title\%3a\%22Hospital+Episode+Stati stics\%2c+Admitted+patient+care+-+England\%22\&sort=Relevance\&size=10\&page=1\#top.

39. Fiske J, Frenkel H, Griffiths J, Jones V, British Society of G, British Society for D, et al. Guidelines for the development of local standards of oral health care for people with dementia. Gerodontology. 2006;23 Suppl 1:5-32.

40. NICE. NICE - Clinical Knowledge Summaries: Palliative care - oral2015 22/01/2016;

2016(January). Available from: http://cks.nice.org.uk/palliative-care-oral\#!annual know upd. 


\section{Tables and Figures}

\section{Figure 1 Search terms}

1. (pulmonary or respiratory or lung) and (disease $\$$ or infection $\$$ or condition $\$$ ) (all fields)

2. (pneumonia or respiratory tract infection or RTI) (all fields)

3. (chronic obstructive pulmonary dis $\$$ or COPD) (all fields)

4. (dysphagia or aspirat\$ or ventil\$) (all fields)

5. (pulmonary or lung or respiratory) and (cancer or neoplasm) (all fields)

6. asthma or tuberculosis (all fields)

7. (oral or dental) and (health or hygiene or disease $\$$ or care or infection) (all fields)

8. (periodon $\$$ or gum) and disease (all fields)

9. (caries or tooth decay or DMFT) (all fields)

10. (plaque or oral bacteria or respiratory pathogen) (all fields)

11. (toothbrush $\$$ or tooth brush $\$$ or chlorhexidine) (all fields)

12. (systematic review) (all fields)

13. (meta ana $\$$ or meta-ana $\$$ ) (all fields)

Cochrane, PubMed, OVID (Embase, MEDLINE (R), PsycINFO) 
Figure 2 Flow diagram

PRISMA 2009 Flow Diagram

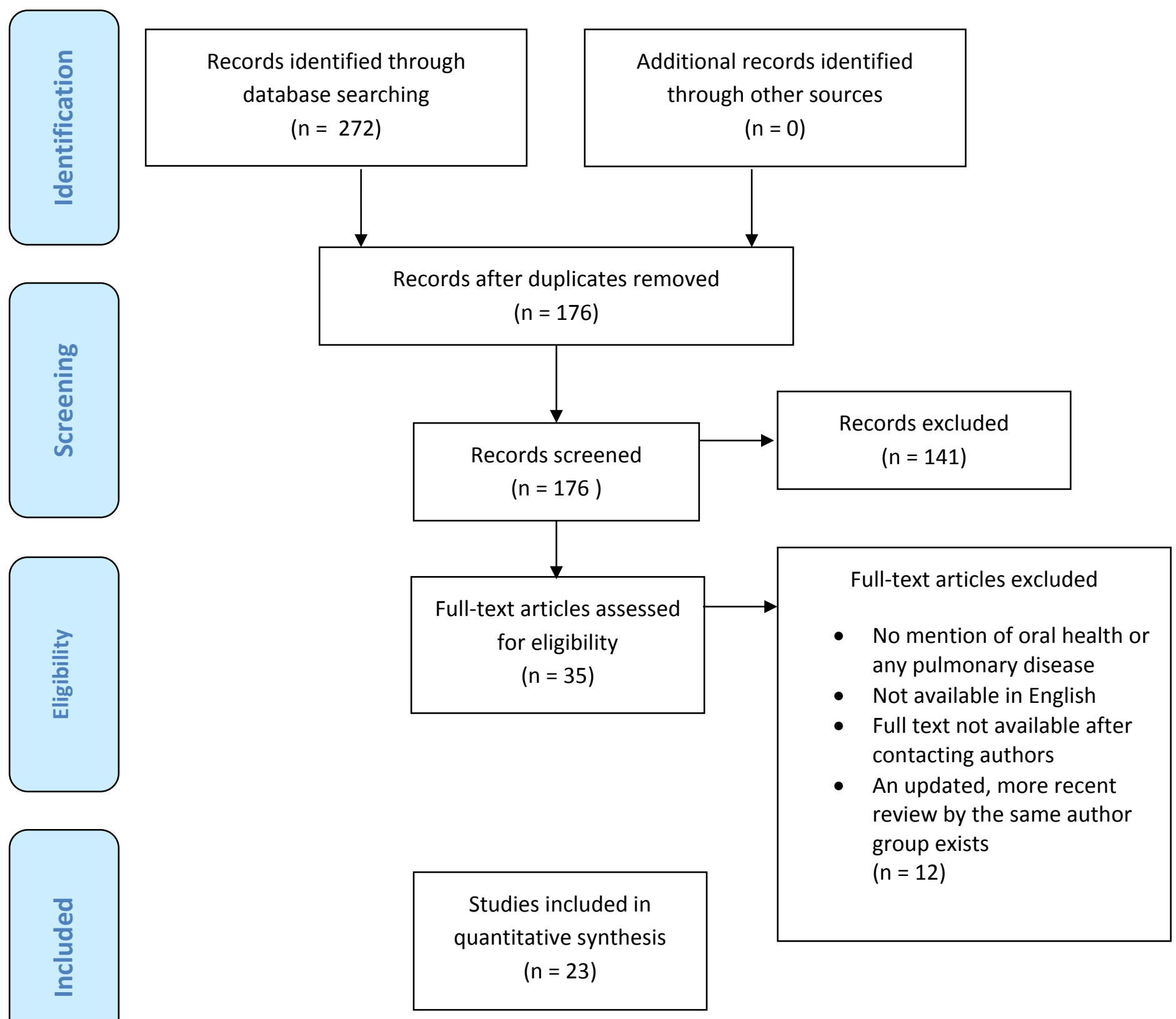


Table 1 Included papers 


\begin{tabular}{|c|c|c|c|c|c|c|}
\hline 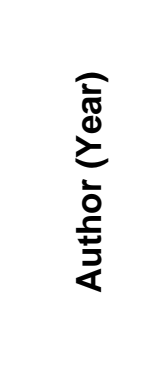 & 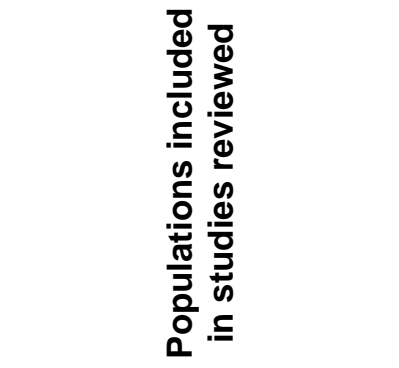 & 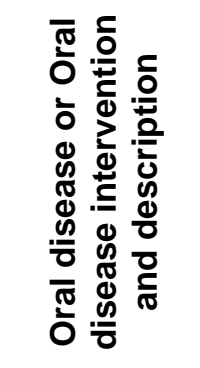 & 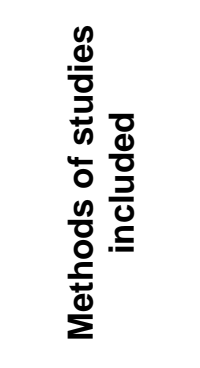 & Results & 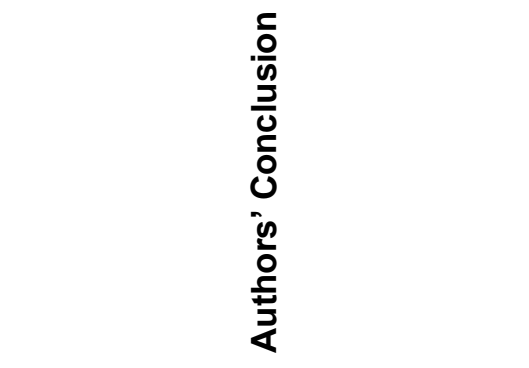 & $\frac{\gtrless}{\frac{Z}{\bar{T}}}$ \\
\hline $\begin{array}{l}\text { Azarpazh } \\
\text { ooh and } \\
\text { Leake } \\
(2006) \\
(34)\end{array}$ & $\begin{array}{l}\text { Pneumonia: ICU, Outpatients } \\
\text { Clinics, Nursing Homes. } \\
\text { COPD: General population } \\
\text { including Veterans in a } \\
\text { longitudinal study with more } \\
\text { focus on elderly. } \\
\text { Reversibility: ICU, Nursing } \\
\text { Homes, Hospital patients who } \\
\text { required ventilation who were } \\
\text { followed up until discharge. }\end{array}$ & $\begin{array}{l}\text { I]Caries } \\
\text { II] Periodontal } \\
\text { Disease. } \\
\text { III] Use of } \\
\text { Tooth } \\
\text { Brushing, } \\
\text { Topical } \\
\text { Antiseptic, } \\
\text { Topical } \\
\text { Antimicrobial, } \\
\text { Oral Care } \\
\text { IV] Caries } \\
\text { pathogens } \\
\text { V] Periodontal } \\
\text { pathogens }\end{array}$ & $\begin{array}{l}\text { Pneumonia: } \\
4 \text { prospective } \\
\text { cohort } \\
\text { I] case-control. } \\
\text { COPD: } 2 \\
\text { case-controls } \\
\text { and II] cross- } \\
\text { sectional } \\
\text { studies. } \\
\text { Reversibility } \\
\text { of } \\
\text { pneumonia: } \\
10 \text { Clinical } \\
\text { Trials }\end{array}$ & $\begin{array}{l}\text { I] Association between pneumonia and oral health. Overall, potential risk } \\
\text { factors for pneumonia were identified as the presence of cariogenic and } \\
\text { periodontal pathogens in saliva and dental plaque (odds ratio [OR] = } 4 \text { to } \\
9.6 \text { ) and dental decay (OR; } 1.2 \text { per decayed tooth). Higher plaque scores } \\
\text { were also shown to be associated with a previous history of respiratory tract } \\
\text { infection (RTI) (Caries and perio/cariogenic pathogens). } \\
\text { II] Association between periodontal disease and COPD. One study } \\
\text { Whole-mouth bone loss scores at baseline: } \mathrm{RR}=1.6 ; 95 \% \mathrm{Cl}=1.2 \text { to } 2.0 .2 \text { ) } \\
\text { ABL status at baseline was an independent risk factor for } \mathrm{COPD} \text {, with } \\
\text { subjects in the worst population quintile of bone loss (mean } \mathrm{ABL}>20 \% \text { per } \\
\text { site) found to be at a significantly higher risk (OR }=1.8 ; 95 \% \mathrm{Cl}=1.3 \text { to } \\
\text { 2.5). Three studies found a weak association (OR/relative risk }[\mathrm{RR}]<2.0) \\
\text { between COPD and oral health measures. } \\
\text { III] Evidence of reversibility of pneumonia. intervention methods for } \\
\text { reducing the colonies of respiratory pathogens in the } \\
\text { oral cavity decreased mortality and morbidity with } \\
\text { levels of evidence of I to II-1. }\end{array}$ & $\begin{array}{l}\text { There is fair evidence of a link between } \\
\text { pneumonia and oral health with an odds } \\
\text { ratio of } 1.2 \text { to } 9.6 \text { depending on oral } \\
\text { health indicators. There is good evidence } \\
\text { that improved oral hygiene and frequent } \\
\text { professional oral health care reduces the } \\
\text { progression of pulmonary disease of high } \\
\text { risk elderly adults living in nursing homes } \\
\text { and in ICU. Except for one study, } 46 \text { all } \\
\text { studies showed that interventions } \\
\text { reduced the incidence of pneumonia } \\
\text { and/or the length of mechanical } \\
\text { ventilation. However, none of the studies } \\
\text { measured a decrease in plaque by the } \\
\text { end of the trials, leaving us in the dark as } \\
\text { to whether the interventions worked } \\
\text { through reducing plaque or some other } \\
\text { means. }\end{array}$ & $\begin{array}{l}\text { Moderate } \\
(7 / 11) . \\
\text { No conflict of } \\
\text { interest } \\
\text { stated, grey } \\
\text { literature not } \\
\text { searched, } \\
\text { publication } \\
\text { bias not } \\
\text { addressed }\end{array}$ \\
\hline $\begin{array}{l}\text { Shi et al } \\
(2013) \\
(19)\end{array}$ & $\begin{array}{l}\text { Critically ill patients receiving } \\
\text { mechanical ventilation. }\end{array}$ & $\begin{array}{l}\text { I] CHX } \\
\text { antiseptic } \\
\text { mouth rinse or } \\
\text { gel compared } \\
\text { to treatment } \\
\text { without the } \\
\text { active } \\
\text { ingredient } \\
\text { chlorhexidine) } \\
\text { or usual } \\
\text { care, (with or } \\
\text { without tooth } \\
\text { brushing). }\end{array}$ & $35 \mathrm{RCTs}$ & $\begin{array}{l}\text { I)Effect of intervention on incidence of VAP } \\
\text { There is moderate quality evidence from } 17 / 35 \mathrm{RCTs} \text { that the use of } \mathrm{CHX} \\
\text { (either as a mouth rinse or a gel) reduces the odds of developing VAP (OR } \\
0.60,95 \% \mathrm{CI} 0.47 \text { to } 0.77, \mathrm{P}<0.001,12=21 \% \text { ) with an NNT of } 15(95 \% \mathrm{Cl} \\
10 \text { to } 34 \text { ). In children }(3 / 35) \mathrm{OH} \text { with } \mathrm{CHX} \text { does not show a statistically } \\
\text { different reduction in VAP when compared with placebo. } \\
\text { Weak evidence that povidone iodine rinse is more effective than saline in } \\
\text { reducing VAP (OR } 0.35,95 \% \mathrm{Cl} 0.19 \text { to } 0.65, \mathrm{P}=0.0009,12=53 \% \text { ) (two } \\
\text { studies, } 206 \text { participants, high risk of bias). We found no evidence of a } \\
\text { difference between a saline swab and a saline rinse with regard to the } \\
\text { reduction of VAP (OR } 0.65,95 \% \mathrm{Cl} 0.37 \text { to } 1.14, \mathrm{P}=0.13, \mathrm{I}=41 \% \text { ) (two } \\
\text { studies, } 83 \text { participants, high risk of bias), and very weak evidence that use } \\
\text { of both a saline swab and a saline rinse may be more effective than a saline }\end{array}$ & $\begin{array}{l}\text { I] There is good evidence that effective } \\
\text { OHC is important for ventilated patients } \\
\text { in intensive care. } \\
\text { II] OHC that includes either chlorhexidine } \\
\text { mouthwash or gel is } \\
\text { associated with a } 40 \% \text { reduction in the } \\
\text { odds of developing VAP in critically ill } \\
\text { adults. } \\
\text { III] There is no } \\
\text { evidence of a difference in the outcomes } \\
\text { of mortality, duration of mechanical } \\
\text { ventilation or duration of ICU stay. There } \\
\text { is no evidence that OHC including both }\end{array}$ & $\begin{array}{l}\text { High (11/11) } \\
\text { Fulfilled all } \\
\text { AMSTAR } \\
\text { criteria }\end{array}$ \\
\hline
\end{tabular}




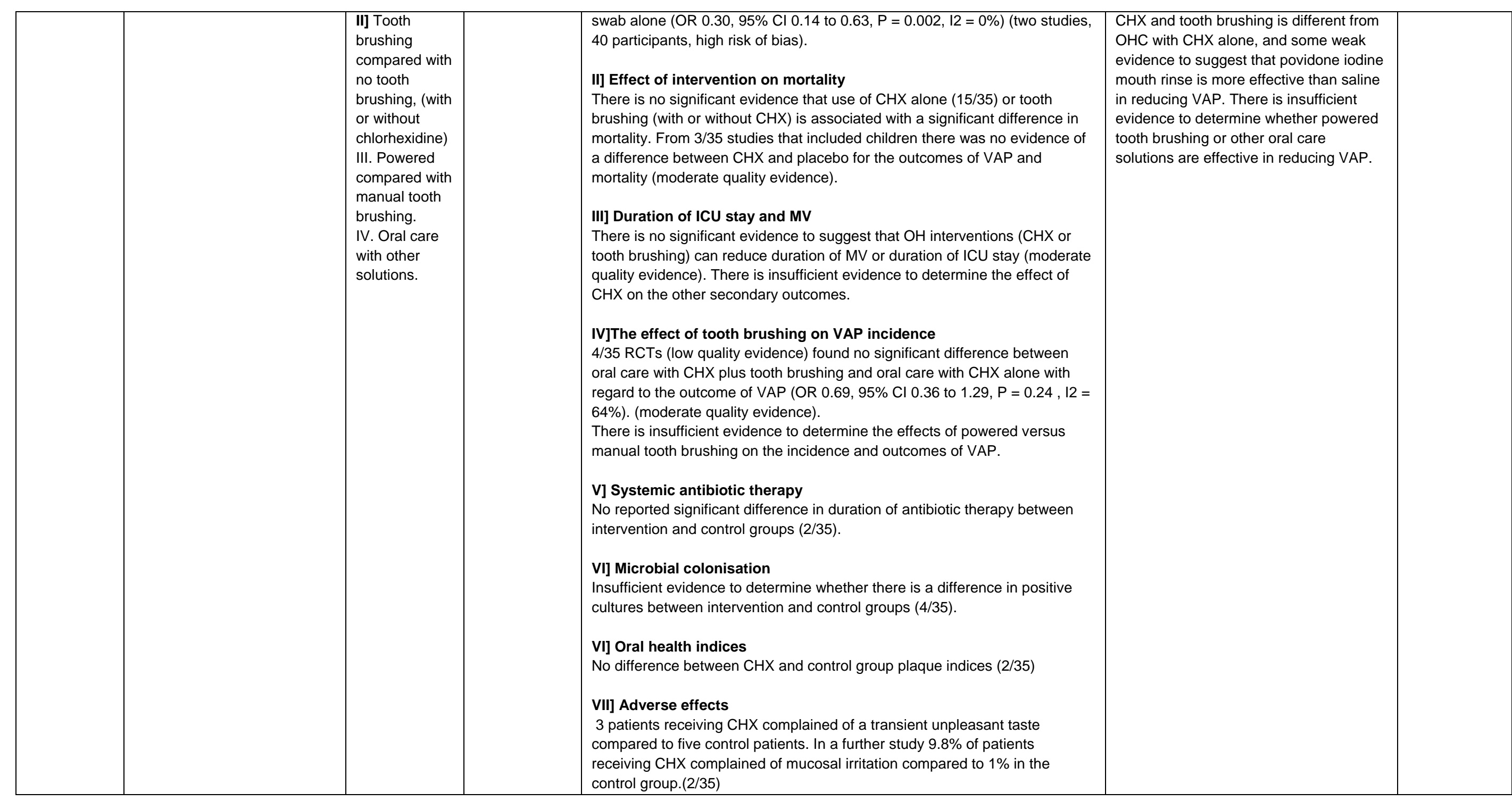




\begin{tabular}{|c|c|c|c|c|c|c|}
\hline $\begin{array}{l}\text { Kaneoka et } \\
\text { al. (2015) } \\
(27)\end{array}$ & $\begin{array}{l}\text { I] Nursing home residents } \\
\text { (3/5) (of these } 2 / 5 \text { stable } \\
\text { physical and cognitive } \\
\text { function), mean age }>80 \text {. } \\
\text { II] Neuro-intensive care unit, } \\
\text { mean age } 36(1 / 5) \text {. } \\
\text { III] Rehabilitation unit mean } \\
\text { age } 69(1 / 5) \text {. } \\
\text { IV] Did not include participants } \\
\text { at high risk of developing } \\
\text { pneumonia e.g. NG tubes or } \\
\text { severe dementia. }\end{array}$ & $\begin{array}{l}\text { I] } \mathrm{CHX} 0.2 \% \\
\text { rinse gargled } \\
\text { BD }(2 / 5) \\
\text { II]"Routine oral } \\
\text { care" }(3 / 5) \\
\text { III] } \\
\text { "Professional } \\
\text { oral care" } \\
(3 / 5)\end{array}$ & 5 RCTs & $\begin{array}{l}\text { I] Incidence of pneumonia: } \\
\text { Individually, } 0 / 4 \mathrm{RCTs} \text { showed significant } \mathrm{RR} \text { for oral care in preventing } \\
\text { pneumonia in non-ventilated, but when combine din meta-analysis a } \\
\text { significant preventative effect was found. Combined effect of mechanical oral } \\
\text { care in combination with professional care significantly reduced the risk for } \\
\text { non-VAP (RR, } 0.61 ; 95 \% \mathrm{Cl}, 0.40-0.92 ; \mathrm{P}=.02) \text {. } \\
\text { II] Preventing fatal pneumonia } \\
\text { Pooled RR from } 2 \mathrm{RCTs} \text { for fatal pneumonia was significant }(\mathrm{RR}, 0.41 ; 95 \% \\
\mathrm{Cl}, 0.23-0.71 ; \mathrm{P}=.002) \text { with no statistical heterogeneity }(\mathrm{X} 2=0.94 ; \mathrm{df}=1 ; \mathrm{P} \\
=.33 ; \mathrm{I} 2=0 \% \text { ). Mechanical oral care significantly reduced the risk for fatal } \\
\text { pneumonia in elderly nursing home residents. }\end{array}$ & $\begin{array}{l}\text { I] There is moderate evidence to suggest } \\
\text { that non-VAP incidence is reduced when } \\
\text { mechanical and professional oral care } \\
\text { are combined. } \\
\text { II] Moderate evidence that mechanical } \\
\text { oral care can lead to a risk reduction in } \\
\text { fatal pneumonia. } \\
\text { III] Caution in interpretation due to risk of } \\
\text { bias in the included trials. }\end{array}$ & $\begin{array}{l}\text { High }(10 / 11) \\
\text { No list of } \\
\text { excluded } \\
\text { papers }\end{array}$ \\
\hline $\begin{array}{l}\text { Vilela et al. } \\
(2015) \\
(30)\end{array}$ & $\begin{array}{l}\text { ICU: Mixed, trauma, surgical, } \\
\text { general, respiratory. }\end{array}$ & $\begin{array}{l}\text { I]CHX } \\
0.12 \% \\
\text { solution, } 0.2 \% \\
\text { solution, } 2 \% \\
\text { solution } \\
\text { II] } \\
\text { Adjuncts: } \\
\text { i) TB, } \\
\text { ii) sodium } \\
\text { bicarbonate } \\
\text { iii) colistin. }\end{array}$ & $\begin{array}{l}13 \text { RCTs , } 1 \\
\text { ECR }\end{array}$ & $\begin{array}{l}\text { I] Incidence of nosocomial pneumonia } \\
9 / 13 \text { RCTs found topical CHX reduced incidence of } \\
\text { NP. } 4 / 9 \text { RCTs did not find statistically } \\
\text { significant differences among the groups. 1/9RCTs observed a delay in the } \\
\text { establishment of NP. }\end{array}$ & $\begin{array}{l}\text { Fair evidence exists to suggest that } \\
\text { the control of oral biofilm reduces the } \\
\text { incidence of } \\
\text { NP at concentrations of } 0.12 \% \text { and } \\
\text { above. Though } 0.2 \% \text { appears to be the } \\
\text { most effective. }\end{array}$ & $\begin{array}{l}\text { Moderate } \\
(6 / 11) \\
\text { No grey } \\
\text { literature } \\
\text { search, no list } \\
\text { of excluded } \\
\text { papers, no } \\
\text { pooling of } \\
\text { data, } \\
\text { publication is } \\
\text { not } \\
\text { addressed, } \\
\text { conflict of } \\
\text { interest not } \\
\text { stated. }\end{array}$ \\
\hline $\begin{array}{l}\text { Silvestri et al. } \\
(2014) \\
(28)\end{array}$ & $\begin{array}{l}\text { ICU: } \\
\text { Mixed medical/surgical }(9 / 22), \\
\text { trauma }(2 / 22), \text { surgical }(2 / 22), \\
\text { respiratory }(1 / 22), \\
\text { medical(1/22), neurology } \\
(1 / 22), \\
\text { cardiac surgery }(3 / 22), \\
\text { paediatric cardiac surgery } \\
(1 / 22), \\
\text { paediatric ICU }(2 / 22),\end{array}$ & $\begin{array}{l}\text { I] CHX } \\
\text { preparations } \\
0.12 \%, 0.2 \% \text {, } \\
0.2 \% \mathrm{CHX} \\
\text { solution, } \\
0.5 \% \mathrm{CHX} \\
\text { ointment } \\
\text { II]Adjuncts: } \\
\text { TB, sodium } \\
\text { bicarbonate }\end{array}$ & 22 RCTs & $\begin{array}{l}\text { I] Effects of CHX on NP } \\
\text { Good evidence to suggest that } \mathrm{CHX} \text { significantly reduces the number of } \\
\text { critically-ill patients who develop NP (OR } 0.66 ; 95 \% \mathrm{Cl} 0.51-0.85 ; \mathrm{P}<0.001) \\
\text { and VAP (OR } 0.68,95 \% \mathrm{Cl} 0.53-0.87, \mathrm{P}<0.01) \text {. The NNT was } 23.85(95 \% \mathrm{Cl} \\
23.83-23.87) \text {. The } \\
\text { subgroup analysis reveals reduction in NP is significant only in surgical } \\
\text { patients. } \\
\text { II] Effect of CHX on oral bacteriome: Gram positive and gram negative } \\
\text { bacteria } \\
\text { Good evidence to suggest } \mathrm{CHX} \text { reduced the incidence of pneumonia caused } \\
\text { by gram positive (OR } 0.41 ; 95 \% \mathrm{Cl} 0.19-0.85 ; \mathrm{P}=0.02) \text {, and gram negative } \\
\text { (OR } 0.68 ; 95 \% \mathrm{Cl} 0.51-0.90 ; \mathrm{P}<0.01) \text { bacteria. }\end{array}$ & $\begin{array}{l}\text { I] Good evidence to suggest that CHX } \\
\text { reduces NP and VAP in surgical patients. } \\
\text { II] CHX controls NP due to both } \\
\text { Gram-positive and Gram-negative } \\
\text { bacteria. } \\
\text { III] When micro-organisms are classified } \\
\text { into "normal" } \\
\text { and "abnormal", CHX significantly } \\
\text { reduces pneumonia due to "normal" flora } \\
\text { only. Most, but not all, specific bacteria } \\
\text { caused NP was reduced by CHX. }\end{array}$ & $\begin{array}{l}\text { High }(10 / 11) \\
\text { No list of } \\
\text { excluded } \\
\text { papers }\end{array}$ \\
\hline
\end{tabular}




\begin{tabular}{|c|c|c|c|c|c|c|}
\hline & & & & $\begin{array}{l}\text { III] Effect of CHX on oral bacteriome: normal and abnormal bacteria. } \\
\text { Good evidence to suggest that } \mathrm{CHX} \text { significantly reduced NP due to "normal" } \\
\text { micro-organisms (OR } 0.51 ; 95 \% \mathrm{Cl} 0.33-0.80 ; \mathrm{P}<0.01) \text {. No significant } \\
\text { reduction seen in NP due to "abnormal" bacteria (OR } 0.78 ; 95 \% \mathrm{Cl} 0.54 \text { - } \\
1.21 ; \mathrm{P}=0.16 \text { ). } \\
\text { III] Effect of CHX on mortality from pneumonia Non-significant, increase } \\
\text { in the ORs for mortality in the } \mathrm{CHX} \text { group (OR } 1.11 ; 95 \% \mathrm{Cl} 0.92-1.33 \text {; } \\
\mathrm{P}=0.28 \text { ). }\end{array}$ & $\begin{array}{l}\text { IV] CHX shows no significant effect on } \\
\text { mortality from pneumonia in the surgical, } \\
\text { medical or paediatric population. }\end{array}$ & \\
\hline $\begin{array}{l}\text { El-Rabbany } \\
\text { et al. (2015) } \\
\text { (29) }\end{array}$ & $\begin{array}{l}\text { I] Adults in hospital }(25 / 28) \\
\text { ICU mean ages } 32-62 \\
\text { II] Adults in nursing home } \\
\text { (2/28) mean age } 82 \text {. } \\
\text { III] Paediatric ICU (2/28) mean } \\
\text { age } 12-34.5 \text { months. }\end{array}$ & $\begin{array}{l}\mathrm{CHX}, \mathrm{TB} \text { and } \\
\mathrm{OH} \text {, oral and } \\
\text { pharyngeal } \\
\text { suction, } \\
\text { iodine, sodium } \\
\text { bicarbonate, } \\
\text { topical } \\
\text { application of } \\
\text { a non- } \\
\text { absorbable } \\
\text { anti-biotic } \\
\text { solution, } \\
\text { professional } \\
\text { oral health } \\
\text { cleaning }\end{array}$ & $28 \mathrm{RCTs}$ & $\begin{array}{l}\text { I] Effect of OH on pneumonia incidence } \\
\text { Fair evidence exists to suggest a relationship between good oral care and } \\
\text { lower rates of hospital acquired pneumonia. } \\
7 / 28 \text { RCTs showed positive and significant effect. 12/28 RCTs showing no } \\
\text { significant difference. TB was demonstrated to be effective in significantly } \\
\text { reducing pneumonia incidence in RCTs. Professional oral health cleaning } \\
\text { (1/28), antibiotic solution ( } 1 / 28) \text {, and } 10 \% \text { povidone iodine (1/28) were shown } \\
\text { to significantly reduce pneumonia rates. } \\
\text { II] Febrile episodes from pneumonia } \\
2 / 28 \text { RCTs showed a reduction in the number of cases of fever when using } \\
\text { TB with } 1 \% \text { iodine or scaling with electric TB. Both of these RCTs were in } \\
\text { nursing home settings. } \\
\text { III] Mortality associated with pneumonia. } \\
\text { One short term study found that there were fewer deaths from pneumonia in } \\
\text { in the intervention group. } \\
\text { IV] Oral health indices } \\
\text { Tooth brushing found to significantly reduce plaque levels (5/28) }\end{array}$ & $\begin{array}{l}\text { I] Fair evidence to suggest that } \mathrm{OH} \text { is a } \\
\text { viable method of reducing risk of Hap or } \\
\text { VAP in both intensive and long-term care } \\
\text { facilities. Conversely, evidence } \\
\text { supporting the effectiveness of other oral } \\
\text { care solutions that do not include } \mathrm{CHX} \mathrm{s} \\
\text { still remains scarce and methodologically } \\
\text { weak. } \\
\text { II] Weak evidence exists to suggest a } \\
\text { reduction in febrile days associated with } \\
\text { pneumonia in nursing homes. } \\
\text { II] There was heterogeneity between the } \\
\text { studies (no meta-analysis was carried } \\
\text { out in this paper) and as such results } \\
\text { should be interpreted with caution. } \\
\text {. }\end{array}$ & $\begin{array}{l}\text { High }(9 / 11) \\
\text { No analysis of } \\
\text { publication } \\
\text { bias, no meta- } \\
\text { analysis. }\end{array}$ \\
\hline
\end{tabular}




\begin{tabular}{|c|c|}
\hline Key Questions to be addressed & \\
\hline $\begin{array}{l}\text { - Do oral hygiene interventions reverse oral diseases when } \\
\text { incidence of pneumonia reduces? }\end{array}$ & - Research is required in community settings \\
\hline $\begin{array}{l}\text { Does good regular oral hygiene (self-care, carers-care, } \\
\text { professional-care) impact on risk of pulmonary disease? } \\
\text { - As periodontal disease increases, does the risk of pulmonary } \\
\text { disease increase? }\end{array}$ & - Longitudinal research with cohorts of older adults required \\
\hline - What value do patients place on oral health care in frail states? & $\begin{array}{l}\text { Anecdotally this depends on what value they placed on it } \\
\text { before they were frail and the views of their carers. If they } \\
\text { and their carers were aware of the importance of good oral } \\
\text { hygiene (daily care), it may have wider health implications? }\end{array}$ \\
\hline $\begin{array}{l}\text { - Is it cost-effective to implement oral hygiene interventions as part } \\
\text { of care pathway of frail patients? }\end{array}$ & $\begin{array}{l}\text { - The costs and benefits associated with the management of } \\
\text { pneumonia and repeated chest infections must be } \\
\text { outweighed by the cost of maintaining oral hygiene } \\
\text { - } \mathrm{CHX} \text { is shown to be cost-effective in VAP, but there no } \\
\text { evidence from community patients; hence, there is a need } \\
\text { for more studies in community }\end{array}$ \\
\hline
\end{tabular}

